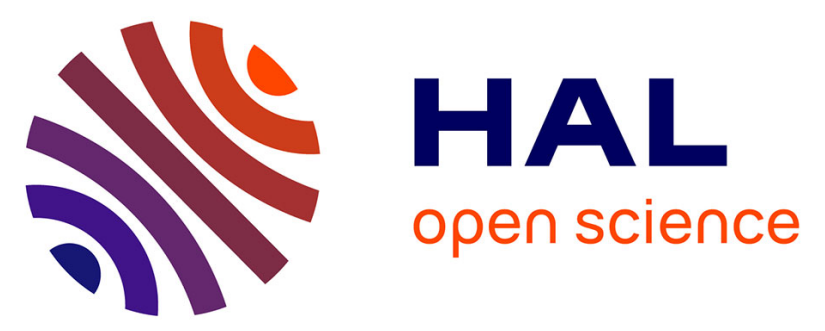

\title{
A thermostable triple mutant of pyranose 2-oxidase from Trametes multicolor with improved properties for biotechnological applications
}

Oliver Spadiut, Katrin Radakovits, Ines Pisanelli, Clara Salaheddin, Montarop Yamabhai, Tien-Chye Tan, Christina Divne, Dietmar Haltrich

\section{To cite this version:}

Oliver Spadiut, Katrin Radakovits, Ines Pisanelli, Clara Salaheddin, Montarop Yamabhai, et al.. A thermostable triple mutant of pyranose 2-oxidase from Trametes multicolor with improved properties for biotechnological applications. Biotechnology Journal, 2009, 4 (4), pp.525-n/a. 10.1002/biot.200800260 . hal-00477773

\section{HAL Id: hal-00477773 \\ https://hal.science/hal-00477773}

Submitted on 30 Apr 2010

HAL is a multi-disciplinary open access archive for the deposit and dissemination of scientific research documents, whether they are published or not. The documents may come from teaching and research institutions in France or abroad, or from public or private research centers.
L'archive ouverte pluridisciplinaire HAL, est destinée au dépôt et à la diffusion de documents scientifiques de niveau recherche, publiés ou non, émanant des établissements d'enseignement et de recherche français ou étrangers, des laboratoires publics ou privés. 


\section{A thermostable triple mutant of pyranose 2-oxidase from Trametes multicolor with improved properties for biotechnological applications}

\begin{tabular}{|c|c|}
\hline Journal: & Biotechnology Journal \\
\hline Manuscript ID: & BIOT-2008-0260.R2 \\
\hline Wiley - Manuscript type: & Research Article \\
\hline $\begin{array}{l}\text { Date Submitted by the } \\
\text { Author: }\end{array}$ & 28-Nov-2008 \\
\hline Complete List of Authors: & $\begin{array}{l}\text { Spadiut, Oliver; Universität für Bodenkultur, Food Sciences and } \\
\text { Technology } \\
\text { Radakovits, Katrin; Universität für Bodenkultur, Food Sciences and } \\
\text { Technology } \\
\text { Pisanelli, Ines; Universität für Bodenkultur, Food Sciences and } \\
\text { Technology } \\
\text { Salaheddin, Clara; Universität für Bodenkultur, Food Sciences and } \\
\text { Technology } \\
\text { Yamabhai, Montarop; Suranaree University of Technology, School } \\
\text { of Biotechnology } \\
\text { Tan, Tien-Chye; Royal Institute of Technology KTH, School of } \\
\text { Biotechnology } \\
\text { Divne, Christina; Royal Institute of Technology KTH, School of } \\
\text { Biotechnology } \\
\text { Haltrich, Dietmar; Universität für Bodenkultur, Food Sciences and } \\
\text { Technology }\end{array}$ \\
\hline Keywords: & $\begin{array}{l}\text { rational protein design, enzyme engineering, flavoprotein, thermal } \\
\text { stability }\end{array}$ \\
\hline
\end{tabular}

\section{今scholaroNE" \\ Manuscript Central}


((5941 words))

\section{Research Article}

A thermostable triple mutant of pyranose 2-oxidase from Trametes multicolor with improved properties for biotechnological applications

Oliver Spadiut ${ }^{1}$, Katrin Radakovits ${ }^{1}$, Ines Pisanelli ${ }^{1}$, Clara Salaheddin ${ }^{1}$, Montarop Yamabhai $^{2}$, Tien-Chye $\operatorname{Tan}^{3}$, Christina Divne $^{3} \&$ Dietmar Haltrich $^{1,4^{*}}$

1 Department of Food Sciences and Technology, BOKU - University of Natural Resources and Applied Life Sciences, A-1190 Vienna, Austria

2 School of Biotechnology, Suranaree University of Technology, Nakhon Ratchasima 30000, Thailand

3 School of Biotechnology, KTH, Albanova University Centre, SE-106 91 Stockholm, Sweden

4 Vienna Institute of BioTechnology VIBT, A-1190 Vienna, Austria

*to whom correspondence should be addressed at:

Abteilung für Lebensmittelbiotechnologie, Universität für Bodenkultur, Muthgasse 18, A-1190 Wien, Austria

dietmar.haltrich@boku.ac.at, tel.: +43-1-36006-6275, fax +43-1-36006-6251

\footnotetext{
$1 \quad$ Abstract

2 In order to increase the thermal stability and the catalytic properties of pyranose 3 oxidase (P2Ox) from Trametes multicolor towards its poor substrate D-galactose and
} 
4 the alternative electron acceptor 1,4-benzoquinone (1,4-BQ), we designed the triple-

5 mutant T169G/E542K/V546C. Whereas the wild-type enzyme clearly favors D-

6 glucose as its substrate over D-galactose [substrate selectivity $\left(k_{\text {cat }} / \mathrm{K}_{\mathrm{M}}\right)_{\mathrm{Glc}} /$

$\left.7\left(k_{\mathrm{cat}} / \mathrm{K}_{\mathrm{M}}\right)_{\mathrm{Gal}}=172\right]$, the variant oxidizes both sugars equally well $\left[\left(k_{\mathrm{cat}} / \mathrm{K}_{\mathrm{M}}\right)_{\mathrm{Glc}} /\right.$

$\left.8\left(k_{\mathrm{cat}} / \mathrm{K}_{\mathrm{M}}\right)_{\mathrm{Gal}}=0.69\right]$, which is of interest for food biotechnology. Furthermore, the

9 variant showed lower $\mathrm{K}_{\mathrm{M}}$ values and approx. tenfold higher $k_{\text {cat }}$ values for 1,4-BQ

10 when D-galactose was used as the saturating sugar substrate, which makes this

11 enzyme particularly attractive for use in biofuel cells and enzyme-based biosensors.

12 In addition to the altered substrate specificity and reactivity, this mutant also shows

13 significantly improved thermal stability. The half-life time at $60^{\circ} \mathrm{C}$ was

14 approximately $10 \mathrm{hrs}$, compared to 7.6 minutes for the wild-type enzyme. We

15 performed successfully small-scale bioreactor pilot conversion experiments of D-

16 glucose/D-galactose mixtures at both $30^{\circ} \mathrm{C}$ and $50^{\circ} \mathrm{C}$, showing the usefulness of this

17 P2Ox variant in biocatalysis as well as the enhanced thermal stability of the enzyme.

18 Moreover, we determined the crystal structure of the mutant in its unligated form at

$191.55 \AA$ resolution. Modeling D-galactose in position for oxidation at $\mathrm{C} 2$ into the

20 mutant active site shows that substituting Thr for Gly at position 169 favorably

21 accommodates the axial C4 hydroxyl group that would otherwise clash with Thr169

22 in the wild-type.

23 Keywords: flavoprotein; rational protein design; enzyme engineering; thermal

24 stability; biofuel cell; enzymatic batch conversion

251 Introduction 
26 Pyranose 2-oxidase (P2Ox; pyranose:oxygen 2-oxidoreductase; glucose 2-oxidase;

27 EC 1.1.3.10), a flavoprotein found widespread in wood-degrading basidiomycetes, 28 catalyzes the oxidation of different aldopyranoses at $\mathrm{C} 2$ to the corresponding 229 ketoaldoses, producing $\mathrm{H}_{2} \mathrm{O}_{2}$ as a by-product [1-3]. It is a homotetrameric enzyme,

30 typically of a molecular mass of $\sim 270 \mathrm{kDa}$ with each of the four $68-\mathrm{kDa}$ subunits

31 carrying one flavin adenine dinucleotide (FAD) covalently bound [4]. The crystal

32 structure of P2Ox from Trametes multicolor was determined at $1.8 \AA$ A resolution [5].

33 An intriguing structural feature of P2Ox is its large internal cavity, from which the

34 active sites are accessible. Four solvent channels lead from the surface of the

35 polypeptide into this cavity through which substrates must enter before accessing the

36 narrow active-site channels of P2Ox. The monosaccharide D-glucose is its preferred

37 substrate and it shows high activities with e.g. D-xylose and L-sorbose, whereas D-

38 galactose is a rather poor substrate with only $5.7 \%$ relative activity [6]. Oxidation of

39 D-galactose at position C2 is interesting from an applied point of view, since 2-keto-

40 D-galactose can be easily reduced at position C1 to yield D-tagatose [7], which is

41 used as a non-cariogenic, low caloric sweetener in food industry. Lactose, which is 
42 available in large amounts as a by-product of the cheese and dairy industry, can be

43 hydrolyzed enzymatically, and thus provides an amply supply of D-glucose and D-

44 galactose. For effective biotechnological applications, the catalytic activity of P2Ox

45 with D-galactose, however, is too low, leading to either very long conversion times

46 or disproportionate amounts of required enzyme. Additionally, a conversion at

47 elevated temperatures is desirable, as catalytic activities increase with higher

48 temperatures and also undesired microbiological growth is avoided during

49 conversions at increased temperatures. Besides applications in food industry, P2Ox

50 is becoming attractive for enzymatic biosensors and biofuel cells. Biofuel cells

51 convert sugars into electrical energy by employing oxidoreductases as an anodic

52 biocomponent, and coupling this with a suitable enzyme on the cathode [8]. In

53 mediated electron transfer, certain mediators such as quinones [9] or osmium redox

54 polymers [10] collect the electrons from the prosthetic group of the enzymes and

55 transfer them to a graphite electrode. To improve the performance of biofuel cells it

56 is crucial to increase both the catalytic activity and the stability of the enzymes

57 applied. Rational protein design to change substrate specificity and reactivity has

58 already been successfully performed for oxidoreductases, hydrolases and

59 transferases [11], and thus provides an excellent tool for adapting P2Ox to the

60 above-mentioned biotechnological applications. In order to improve P2Ox from

61 Trametes multicolor with respect to its catalytic activity with the poor substrate D-

62 galactose and the alternative electron acceptor 1,4-benzoquinone as well as thermal

63 stability, we combined different mutations, which had previously shown positive

64 effects with respect to the properties of the respective single mutants [12-14]. The

65 mutation E542K, which is located on the surface of the internal cavity, was found to 
66 kinetically stabilize the enzyme as well as to improve its catalytic properties to some

67 extent [12]. Furthermore, Thr169 is thought to affect substrate specificity of P2Ox to

68 some extent. D-Galactose differs from D-glucose by having the C-4 hydroxyl group

69 in axial position rather than equatorial. As described elsewhere, we presume that the

70 axial C-4 hydroxyl group of D-galactose appears sterically hindered by the side

71 chain of Thr169. The replacement of Thr by Gly creates additional space in the

72 active site so that the sugar substrates can be accommodated more easily, resulting

73 in lowered $\mathrm{K}_{\mathrm{M}}$ values for D-galactose [14].

74 Here we report on the detailed biochemical and structural characterization of the

75 resulting P2Ox variant T169G/E542K/V546C, and its possible application for the

76 conversion of D-glucose/D-galactose mixtures at elevated temperatures. To examine

77 the details of the structural effects of the amino-acid substitutions, we also

78 determined the crystal structure of T169G/E542K/V546C in the absence of a ligand 79 at $1.55 \AA$ resolution.

\section{$80 \quad 2$ Material and methods}

\section{$81 \quad 2.1$ Plasmids, microorganism and media}

82 The construction of the $\mathrm{pET} 21 \mathrm{~d}^{+} / \mathrm{P} 2 \mathrm{Ox}$ vector (pHL2), which expresses the His-

83 tagged pyranose 2-oxidase gene from Trametes multicolor under control of the T7

84 promoter, has been described previously [15]. Active, recombinant wild-type P2Ox

85 and the mutant T169G/E542K/V546C were expressed in the E. coli strain BL21 Star

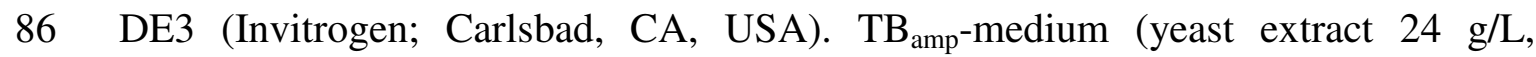

87 peptone from casein $12 \mathrm{~g} / \mathrm{L}$, glycerol $4 \mathrm{~mL} / \mathrm{L} ; \mathrm{KH}_{2} \mathrm{PO}_{4}$-buffer $1 \mathrm{M}, \mathrm{pH} 7.5$ ) was

88 used for cultivation and protein expression under appropriate selective conditions 
89 (ampicillin was added to $0.1 \mathrm{~g} / \mathrm{L}$ ). All chemicals used were from Sigma (Vienna,

90 Austria) and were of the highest grade available.

\section{$91 \quad 2.2$ Generation of mutants}

92 The P2Ox gene was mutated by site-directed mutagenesis using PCR and digestion

93 with DpnI [16]. The plasmid pHL2 as template and primers T169G_fwd (5'-

94 gtcgtcgggggcatgtctacgcacctggggatgcgccacacc-3'), T169Grev (5'-

95 ccagtgcgcgcagcagcetccgtacagatgcgtgacc-3'), E542K_V546C_fwd $\quad$ (5' -

96 gaagcctggtctttgccttcaccttggtgg-3') and E542K_V546C_rev (5' -

97 aagaccaggcttcatgaattgcgggagg-3') were used for mutagenic PCRs. The triple mutant

98 T169G/E542K/V546C was generated by sequential mutagenic PCR steps. The PCR

99 reaction mix contained 2.5 U Pfu DNA polymerase (Fermentas; St. Leon-Rot,

100 Germany), $100 \mathrm{ng}$ of plasmid DNA, $5 \mathrm{pmol}$ of each primer, $10 \mu \mathrm{M}$ of each dNTP

101 and $1 \times$ PCR buffer (Fermentas) in a total volume of $50 \mu \mathrm{L}$. The following

102 conditions were used for mutagenic PCRs: $95^{\circ} \mathrm{C}$ for $4 \mathrm{~min}$, then 30 cycles of $94^{\circ} \mathrm{C}$

103 for $30 \mathrm{~s} ; 56^{\circ} \mathrm{C}$ for $30 \mathrm{~s} ; 72^{\circ} \mathrm{C}$ for $16 \mathrm{~min}$, with a final incubation at $72^{\circ} \mathrm{C}$ for $10 \mathrm{~min}$.

104 After PCR, the methylated template-DNA was degraded by digestion with $10 \mathrm{U}$ of

$105 D p n \mathrm{I}$ at $37^{\circ} \mathrm{C}$ for $3 \mathrm{~h}$. The remaining PCR products were separated by agarose gel

106 electrophoresis and purified using the Wizard SV Gel and PCR-Clean-Up System

107 (Promega; Madison, WI, USA). PCR products $(5 \mu \mathrm{L})$ were transformed into electro-

108 competent $E$. coli BL21 Star DE3 cells. To prove that only the desired mutations had

109 occurred, the P2Ox-encoding gene was sequenced using primers T7promfwd (5'-

110 aatacgactcactataggg-3') and T7termrev (5'-gctagttattgctcagcgg-3 $\left.3^{\prime}\right)$.

\section{$111 \quad 2.3$ Protein expression and purification}


112 Cultures (2 liters) of E. coli BL21 Star DE3 transformants were grown in $\mathrm{TB}_{\mathrm{amp}}$ in

113 shaken flasks at $37^{\circ} \mathrm{C}$ and $160 \mathrm{rpm}$. Protein expression was induced at an $\mathrm{OD}_{600}$ of

$114 \sim 0.5$ by adding lactose to a final concentration of $0.5 \%(\mathrm{w} / \mathrm{v})$. After incubation at

$11525^{\circ} \mathrm{C}$ for further $20 \mathrm{~h}$, approximately $20 \mathrm{~g}$ of wet biomass per liter were harvested by

116 centrifugation at $10,000 \times \mathrm{g}$ for $20 \mathrm{~min}$ and $4{ }^{\circ} \mathrm{C}$, and resuspended in $\mathrm{KH}_{2} \mathrm{PO}_{4}$-buffer

117 (50 mM, pH 6.5) containing the protease inhibitor PMSF $(0.1 \% \mathrm{w} / \mathrm{v})$. After

118 disruption in a continuous homogenizer (APV Systems; Silkeborg, Denmark) the

119 crude cell extract was separated from cell debris by centrifugation $\left(70,400 \times \mathrm{g}, 4^{\circ} \mathrm{C}\right)$

120 and used for protein purification by immobilized metal affinity chromatography

121 (IMAC) with a 10-mL BioRad Profinity IMAC Ni-Charged Resin (Biorad; Vienna,

122 Austria). The column was equilibrated with 10 column volumes (CV) of buffer $(0.05$

$123 \mathrm{M} \mathrm{KH}_{2} \mathrm{PO}_{4}, \mathrm{pH} 6.5,0.5 \mathrm{M} \mathrm{NaCl}, 20 \mathrm{mM}$ imidazole). After the protein sample had

124 been applied to the column it was washed with $3 \mathrm{CV}$ of the same buffer, before

125 proteins were eluted with a linear gradient of $10 \mathrm{CV}$ starting buffer from 20 to 1000

$126 \mathrm{mM}$ imidazole. Active fractions were combined and imidazole was removed by

127 ultrafiltration using an Amicon Ultra Centrifugal Filter Device (Millipore; Billerica,

128 MA, USA) with a 10-kDa cut-off membrane. The concentrated enzymes were

129 washed 3 times with $10 \mathrm{~mL}$ of $\mathrm{KH}_{2} \mathrm{PO}_{4}$-buffer $(50 \mathrm{mM}, \mathrm{pH} 6.5)$ and finally diluted

130 in the same buffer to a protein concentration of $5-10 \mathrm{mg} / \mathrm{mL}$.

\section{$131 \quad 2.4$ Enzyme activity assay}

132 P2Ox activity was measured with the standard chromogenic ABTS [2,2'-azinobis(3-

133 ethylbenzthiazolinesulfonic acid)] assay [6]. A sample of diluted enzyme (10 $\mu \mathrm{L})$

134 was added to $980 \mu \mathrm{L}$ of assay buffer containing horseradish peroxidase (142 $\mathrm{U})$, 
135 ABTS (14.7 mg) and $\mathrm{KH}_{2} \mathrm{PO}_{4}$-buffer (50 mM, pH 6.5). The reaction was started by

136 adding D-glucose $(20 \mathrm{mM})$. The absorbance change at $420 \mathrm{~nm}$ was recorded at $30^{\circ} \mathrm{C}$

137 for $180 \mathrm{~s}$. The molar absorption coefficient at $420 \mathrm{~nm}\left(\varepsilon_{420}\right)$ used was $42.3 \mathrm{mM}^{-1} \cdot \mathrm{cm}^{-}$

1381 . One unit of P2Ox activity was defined as the amount of enzyme necessary for the

139 oxidation of $2 \mu \mathrm{mol}$ of ABTS per min, corresponding to the consumption of $1 \mu \mathrm{mol}$

140 of $\mathrm{O}_{2}$ per min, under assay conditions. Protein concentrations were determined by

141 the Bradford assay [17] using the BioRad Protein Assay Kit with BSA as standard.

\section{$142 \quad 2.5$ Steady-state kinetic measurements}

143 Kinetic constants were calculated by non-linear least-squares regression, fitting the

144 data to the Henri-Michaelis-Menten equation. The catalytic constants were measured

145 for the electron donor substrates D-glucose $(0.1-50 \mathrm{mM})$ and D-galactose $(0.1-200$

$146 \mathrm{mM}$ ) using the standard ABTS assay and air saturation. Additionally, catalytic

147 constants were measured for the alternative electron acceptor of this oxidase, 1,4-

148 benzoquinone (1,4-BQ), with $100 \mathrm{mM}$ of either D-glucose or D-galactose as

149 saturating substrate by adding $10 \mu \mathrm{L}$ of diluted enzyme to $990 \mu \mathrm{L}$ of assay buffer

150 containing either of the two sugar substrates, $\mathrm{KH}_{2} \mathrm{PO}_{4}$-buffer $(50 \mathrm{mM}, \mathrm{pH}$ 6.5) and

151 1,4-BQ $(0.01-2 \mathrm{mM})$. The absorbance change at $290 \mathrm{~nm}$ was recorded at $30^{\circ} \mathrm{C}$ for

$152180 \mathrm{~s}$. The chromophore $\varepsilon_{290}$ used was $2.24 \mathrm{mM}^{-1} \cdot \mathrm{cm}^{-1}$. Steady-state kinetics

153 measurements were carried out both at $30^{\circ} \mathrm{C}$ and $50^{\circ} \mathrm{C}$.

\section{$154 \quad 2.6$ Electrophoresis}

155 To check the purity of the purified P2Ox variants, electrophoresis was performed as 156 described by Laemmli et al. [18]. SDS-PAGE was performed using a 5\% stacking 157 gel and a $10 \%$ separating gel. The system used was the PerfectBlue vertical 
158 electrophoresis apparatus (Peqlab; Erlangen, Germany). The mass standard used was

159 the Precision Plus Protein Dual Color (Biorad). Gels were stained with Coomassie

160 blue.

\section{$161 \quad 2.7$ Kinetic stability}

162 Kinetic stability, as expressed by the half-life time of thermal inactivation $\tau_{1 / 2}$, of the

163 purified wild-type enzyme and the triple mutant was determined by incubating the

164 proteins in appropriate dilutions in $50 \mathrm{mM} \mathrm{KH}_{2} \mathrm{PO}_{4}$-buffer $(\mathrm{pH} 6.5)$ at both $60^{\circ} \mathrm{C}$

165 and $70^{\circ} \mathrm{C}$ for various time intervals and by subsequent measurements of the residual

166 enzyme activity using the standard ABTS assay and D-glucose as substrate. A

167 thermal cycler (thermocycler T3, Biometra; Göttingen, Germany) and thin-walled

168 PCR tubes were used for all thermostability measurements. Residual activities were

169 plotted versus the incubation time and the half-life values of thermal inactivation

$170\left(\tau_{1 / 2}\right)$ were calculated using $\tau_{1 / 2}=\ln 2 / k_{\text {in }}$, where $k_{\text {in }}$ is the observed rate of

171 inactivation.

\section{$172 \quad 2.8$ Batch conversion experiments}

173 Wild-type P2Ox and the variant T169G/E542K/V546C were compared in terms of

174 their ability to oxidize D-glucose and D-galactose to the corresponding 2-ketoaldoses

175 with oxygen as electron acceptor at both $30^{\circ} \mathrm{C}$ and $50^{\circ} \mathrm{C}$. Four batch conversion

176 experiments (each with a volume of $300 \mathrm{~mL}$ ) using equimolar amounts of D-glucose

177 and D-galactose were designed in a way to guarantee a complete conversion of D-

178 galactose within 20 hours for the mutated enzyme and a complete conversion of D-

179 glucose for the wild-type enzyme within reasonable times. The experiments were

180 performed in parallel in a multifermenter (Infors; Bottmingen, Switzerland); these 
181 were initial bioreactor studies proving the applicability of the enzyme variant

182 developed and not aiming at process optimization. The conversion experiments were

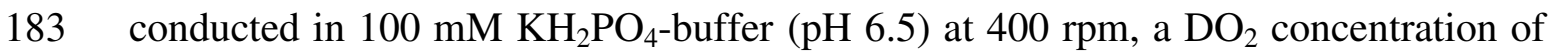

$18415 \%$, both at $30^{\circ} \mathrm{C}$ and $50^{\circ} \mathrm{C}$. Catalase was used in excess $(100,000 \mathrm{U})$ to decompose

$185 \mathrm{H}_{2} \mathrm{O}_{2}$. Depending on the catalytic activity of the enzymes with D-galactose, different

186 amounts of an equimolar mixture of the sugar substrates and biocatalyst

187 concentrations were used for the conversion experiments. For batch conversions

188 (total volume of $300 \mathrm{~mL}$ ) at $30^{\circ} \mathrm{C} 1600 \mathrm{mU}$ wild-type P2Ox and $400 \mathrm{mU}$ mutated

189 enzyme (measured under standard assay conditions with D-galactose as substrate)

190 were used. The kinetic characterization of the enzymes at $50^{\circ} \mathrm{C}$ revealed a specific

191 activity of wild-type $\mathrm{P} 2 \mathrm{Ox}$ with D-galactose of $500 \mathrm{mU} \cdot \mathrm{mg}^{-1}$, of variant

$192 \mathrm{~T} 169 \mathrm{G} / \mathrm{E} 542 \mathrm{~K} / \mathrm{V} 546 \mathrm{C}$ with $20.4 \mathrm{mU} \cdot \mathrm{mg}^{-1}$. Conversions at $50^{\circ} \mathrm{C}$ were conducted

193 with $2400 \mathrm{mU}$ of wild-type and $750 \mathrm{mU}$ T169G/E542K/V546C, respectively.

194 Samples $(2 \mathrm{~mL})$ from the bioconversion experiments were taken periodically, held at

$19595^{\circ} \mathrm{C}$ for $5 \mathrm{~min}$ to inactivate the enzymes and centrifuged. The supernatants were 196 analyzed for their sugar content using high performance anion exchange

197 chromatography with pulsed amperometric detection (HPAEC-PAD), which was

198 carried out using a Dionex DX-500 system (Dionex; Sunnyvale, CA, USA) and a

199 CarboPac PA-1 column $(4 \times 250 \mathrm{~mm})$ at $27^{\circ} \mathrm{C}[19]$.

\section{$200 \quad 2.9$ X-ray crystallographic analysis}

201 Crystals of the P2Ox variant T169G/E542K/V546C were produced using the 202 hanging drop vapor diffusion method [20]. Drops were prepared by equal volumes 203 of $5 \mathrm{mg} / \mathrm{mL}$ protein and reservoir [10\% (w/v) monomethylether polyethylene glycol 
2042000 (mme PEG), $0.1 \mathrm{M}$ Mes (pH 5.2), $50 \mathrm{mM} \mathrm{MgCl} 2,25 \%$ glycerol]. Prior to data

205 collection, the crystals were stabilized using their respective reservoir solution 206 where the PEG concentration had been increased to 50\% (stabilizing solution) 207 followed by vitrification in liquid nitrogen. The protein crystallizes in space group $208 P_{2} 2_{1} 2$ with one molecule in the asymmetric unit. Data were collected using 209 synchrotron radiation at MAX-lab (Lund, Sweden), beamline 1911-3 ( $\lambda=1.0 \AA$ A 100

$210 \mathrm{~K})$. Data were processed using XDS [21]. Phases for the T169G/E542K/V546C 211 structure were obtained by means of Fourier synthesis using the refined model of 212 P2Ox variant H167A as starting model (PDB code 2IGO; [15]. Crystallographic 213 refinement was performed with REFMAC5 [22], including anisotropic scaling, 214 calculated hydrogen scattering from riding hydrogens, and atomic displacement 215 parameter refinement using the translation, libration, screw-rotation (TLS) model. 216 The TLS models were determined using the TLS Motion Determination server 217 (TLSMD; [23]). Corrections of the models were done manually based on $\sigma_{\mathrm{A}^{-}}$ 218 weighted $2 F_{o}-F_{c}$ and $F_{o}-F_{c}$ electron density maps. The $R_{\text {free }}$ reflection sets were kept 219 throughout refinement. All model building was performed with the program $O$ [24] 220 and Coot [25]. Data collection and model refinement statistics are given in Table 5. 221 Structural data are available in the Protein Data Base under the accession number 222 3FDY.

\section{Results}

\section{$225 \quad 3.1$ Generation of mutants}


226 After site-directed mutagenesis was performed as described in the Material and

227 Methods section, the presence of the correct and the absence of undesired mutations

228 in the P2Ox gene were confirmed by DNA sequence analysis. Wild-type P2Ox and

229 the variant T169G/E542K/V546C were expressed in E. coli, purified to apparent

230 homogeneity and concentrated by ultrafiltration. The purity of the resulting enzyme

231 preparations was confirmed by SDS-PAGE (Fig. 1). Routinely, approx. $20 \mathrm{mg}$ of

232 P2Ox protein were obtained per liter culture medium by this procedure.

\section{$233 \quad 3.2$ Kinetic characterization}

234 For determination of the steady-state kinetic constants, initial rates of substrate

235 turnover were recorded over a substrate range of $0.1-50 \mathrm{mM}$ D-glucose and $0.1-200$

$236 \mathrm{mM}$ D-galactose for wild-type $\mathrm{P} 2 \mathrm{Ox}$ and the mutational variant

237 T169G/E542K/V546C using the standard ABTS assay and oxygen (air saturation),

238 both at $30^{\circ} \mathrm{C}$ and $50^{\circ} \mathrm{C}$. Kinetic data are summarized in Table 1. Prior to

239 determination of the kinetic constants it was confirmed that the introduction of the

240 amino acid substitutions in the triple-mutant did not affect the $\mathrm{pH}$ profile of $\mathrm{P} 2 \mathrm{Ox}$

241 activity (data not shown). T169G/E542K/V546C showed an approx. 5-fold

242 decreased Michaelis constant $\mathrm{K}_{\mathrm{M}}$ for D-galactose compared to the wild-type enzyme

243 when air oxygen was the electron acceptor, whereas $K_{M}$ for D-glucose was hardly

244 altered. Yet, turnover numbers $k_{\text {cat }}$ for both sugar substrates were decreased

245 considerably as well, regardless of the temperature used for activity measurements.

246 As a result, the catalytic efficiency $k_{\text {cat }} / K_{M}$ of the mutant was similar to that of the

247 wild-type enzyme with D-galactose but was decreased $\approx 400$-fold with D-glucose,

248 resulting in an enzyme that showed an equal or even higher $k_{\text {cat }} / \mathrm{K}_{\mathrm{M}}$ value for D- 
249 galactose than for D-glucose. In contrast, the wild-type enzyme clearly prefers D-

250 glucose over D-galactose as its sugar substrate as is also expressed by the substrate 251 selectivity values, i.e., the ratio of the catalytic efficiencies $k_{\text {cat }} / K_{M}$ for the two 252 substrates. This value is 172 for the wild-type, while it is 0.69 for $253 \mathrm{~T} 169 \mathrm{G} / \mathrm{E} 542 \mathrm{~K} / \mathrm{V} 546 \mathrm{C}$ at $30^{\circ} \mathrm{C}$.

254 In addition, the kinetic constants were determined for the alternative electron 255 acceptor 1,4-benzoquinone (1,4-BQ) with either D-glucose or D-galactose in 256 saturating concentrations at $30^{\circ} \mathrm{C}$ and $50^{\circ} \mathrm{C}$ (Table 2), and it was found that the three 257 amino acid substitutions dramatically affect the catalytic properties. The $\mathrm{K}_{\mathrm{M}}$ value of 258 the mutant for 1,4-BQ was reduced two to three times compared to the wild-type 259 enzyme, regardless of the sugar substrate used. While the turnover number with D-

260 glucose as saturating substrate was reduced significantly, it increased considerably 261 with D-galactose $(\approx 10$-fold $)$. Compared to the wild-type enzyme, mutant 262 T169G/E542K/V546C showed a 24- and 15-fold increase in its catalytic efficiency 263 at $30^{\circ} \mathrm{C}$ and $50^{\circ} \mathrm{C}$, respectively, for 1,4-BQ and D-galactose as saturating substrate.

\section{$264 \quad 3.3$ Thermal stability}

265 Kinetic stability (the length of the time in which an enzyme remains active before 266 undergoing irreversible inactivation) of wtP2Ox and of variant $267 \mathrm{~T} 169 \mathrm{G} / \mathrm{E} 542 \mathrm{~K} / \mathrm{V} 546 \mathrm{C}$ was determined at $60^{\circ} \mathrm{C}$ and at $70^{\circ} \mathrm{C}$ and a constant $\mathrm{pH}$ of 268 6.5. The inactivation constants $k_{\text {in }}$ and the half-lives of denaturation $\tau_{1 / 2}$ were 269 determined (Table 3), and both enzymes showed first-order inactivation kinetics 270 when analyzed in the $\ln$ (residual activity) versus time plot (Fig. 2). The mutation 271 E542K in combination with T169G and V546C stabilized P2Ox significantly. At 
$27260^{\circ} \mathrm{C}$ the half-life was increased 76-fold compared to the wild-type enzyme. The

273 effect of the mutations on stability is even more pronounced at $70^{\circ} \mathrm{C}$, where $\tau_{1 / 2}$ was 274 increased 350-fold.

\section{$275 \quad 3.4$ Enzymatic batch conversion experiments}

276 In order to assess the effects of the selected amino acid substitutions on the 277 biocatalytic performance of $\mathrm{P} 2 \mathrm{Ox}$, batch conversion experiments using equimolar 278 mixtures of D-glucose and D-galactose were performed with oxygen as electron 279 acceptor (Fig. 3). Reaction conditions were chosen to guarantee reasonable process 280 times in each reactor and were not aimed at process optimization; hence different 281 amounts of enzyme and sugar substrates were used (Table 4). The specific activity 282 of P2Ox when using D-galactose as the substrate and measuring at $30^{\circ} \mathrm{C}$ was 330 $283 \mathrm{mU} \cdot \mathrm{mg}^{-1}$ for the wild-type and $12.2 \mathrm{mU} \cdot \mathrm{mg}^{-1}$ for variant T169G/E542K/V546C. At $28430^{\circ} \mathrm{C}$ the wild-type enzyme clearly preferred D-glucose compared to D-galactose 285 with a conversion rate of $2.0 \mathrm{~g} \cdot \mathrm{L}^{-1} \cdot \mathrm{h}^{-1}$. Only when D-glucose was oxidized 286 completely, D-galactose was converted at a very low rate of $0.02 \mathrm{~g} \cdot \mathrm{L}^{-1} \cdot \mathrm{h}^{-1}$. In 287 contrast to that, mutant T169G/E542K/V546C showed similar conversion rates of 2880.054 and $0.065 \mathrm{~g} \cdot \mathrm{L}^{-1} \cdot \mathrm{h}^{-1}$ for D-glucose and D-galactose. The engineered variant did 289 not prefer either of the sugars as its substrate but converted both of them 290 simultaneously. As is also expressed by the slightly higher $k_{\text {cat }}$ for D-galactose, this 291 monosaccharide was converted at a somewhat faster rate than D-glucose. When the 292 conversion experiments were performed at $50^{\circ} \mathrm{C}$, the wild-type enzyme oxidized D293 glucose initially at a high rate of $8.7 \mathrm{~g} \cdot \mathrm{L}^{-1} \cdot \mathrm{h}^{-1}$ for the first phase of the conversion (up 294 to $45 \mathrm{~min})$. Yet, thermal inactivation of the enzyme resulted in a rapid drop of the 
295 conversion rate over time and P2Ox activity was completely lost after $90 \mathrm{~min}$, as

296 was evident from residual D-glucose left in the reaction mixture and the complete

297 lack of 2-keto-D-galactose. In contrast, variant T169G/E542K/V546C converted

298 both sugar substrates at an almost equal rate of $0.12 \mathrm{~g} \cdot \mathrm{L}^{-1} \cdot \mathrm{h}^{-1}$ resulting in complete

299 conversion of both sugar substrates within $20 \mathrm{~h}$.

300

\section{Discussion}

302 Pyranose oxidase is an enzyme of interest for use in biofuel cells and enzyme-based 303 biosensors as well as for applications in food industry. In several previous studies 304 the improvement of P2Ox both in terms of stability and reactivity was reported. The 305 mutation E542K was found to improve both the kinetic and thermodynamic stability 306 of the enzyme as well as its catalytic properties to some extent $[12,26]$. Other

307 studies showed the positive effects of the mutations V546C [13] and T169G [14] 308 with respect to kinetic properties, especially for the oxidation of the substrate D309 galactose. The replacement of Val by Cys at position 546 in the direct vicinity of the 310 active site of $\mathrm{P} 2 \mathrm{Ox}$ resulted in significantly increased turnover rates for both the 311 sugar substrate and the alternative electron acceptor, albeit at the costs of an 312 increased $\mathrm{K}_{\mathrm{M}}$. We determined the crystal structure of the T169G/E542K/V546C 313 mutant at $1.55 \AA$ resolution and performed theoretical modeling of $\beta$-D-glucose and $314 \beta$-D-galactose in the active site (Fig. 4). The axial C4 hydroxyl in $\beta$-D-galactose 315 cannot be accommodated easily in the active site and clashes with the side chain of 316 Thr169, whereas the $\beta$-D-glucose C4 hydroxyl fits well. In the mutant, Gly169 317 relieves steric hindrance and provides space for the galactose $\mathrm{C} 4$ hydroxyl group to 
318 give a relative decrease in $\mathrm{K}_{\mathrm{M}}$ value. This, at least partly, explains why $\beta$-D-

319 galactose is a poor substrate for wild-type P2Ox, and performs relatively better as

320 substrate for $\mathrm{P} 2 \mathrm{Ox}$ T169G/E542K/V546C. By introducing this mutation we

321 intended to counteract the negative effects on $\mathrm{K}_{\mathrm{M}}$ observed for the V546C mutation.

322 By combining these three different mutations we aimed at creating a thermostable

323 variant of P2Ox, which converts D-galactose and D-glucose concomitantly and at

324 equal rates. This simultaneous conversion of D-glucose and D-galactose is important

325 when e.g. lactose hydrolysates are used as a starting material for the envisaged

326 bioconversion. P2Ox is known to overoxidize its primary reaction product, 2-keto-

327 D-glucose, thus forming 2,3-diketo-D-glucose [27]. Simultaneous conversion of the

328 two sugar substrates will obviously avoid this overoxidation and thus the formation

329 of the undesired by-product. We were further interested in increasing the turnover

330 number for 1,4-benzoquinone, which can be used as electron mediator in biofuel

331 cells and biosensors, in combination with D-galactose as the saturating substrate. In

332 biofuel cells based on mediated electron transfer, suitable mediators gather electrons

333 from the prosthetic group of an enzyme and transfer them to the electrode. In these

334 applications, the measured current represents the actual turnover rate of the

335 immobilized enzyme, and, consequently, an enzyme with increased turnover rates

336 for the mediator will boost the power output of biofuel cells [8, 10] or improve

337 enzyme electrodes [30].

338 Kinetic characterization and comparison of variant T169G/E542K/V546C showed

339 that the substrate selectivity was indeed changed significantly for the mutant.

340 Whereas wtP2Ox clearly prefers D-glucose as its substrate, as indicated by a 341 considerably higher $k_{\text {cat }} / \mathrm{K}_{\mathrm{M}}$ value, T169G/E542K/V546C does not show any clear 
342 preference for either sugar substrate as is evident from comparable catalytic

343 efficiencies. This change in substrate selectivity, however, comes at a cost in $k_{\text {cat }}$,

344 which is reduced for the triple-mutant for both sugar substrates. The altered sugar

345 selectivity is also obvious when performing small-scale conversion experiments,

346 using equimolar mixtures of D-glucose and D-galactose, as found in lactose

347 hydrolysates, as the starting material.

348 Here, the variant oxidized both sugars simultaneously, while the wild-type enzyme

349 converted D-galactose only when D-glucose was exhausted from the reaction

350 mixture. Introducing the E542K mutation in the variant also enabled conversions at

351 higher temperatures, which is preferable because of higher reaction rates and a

352 decreased possibility of microbial contamination. The triple-mutant showed

353 considerably increased thermostability as is evident from the remarkable increase in

354 half-life times, at both $60^{\circ} \mathrm{C}$ and $70^{\circ} \mathrm{C}$, which were improved 76 -fold and 350 -fold,

355 respectively, when compared to the wild-type. Thus, bioconversions based on the

356 thermostable variant will be feasible at temperatures of up to $60^{\circ} \mathrm{C}$.

357 The triple-mutant T169G/E542K/V546C also showed significantly improved

358 catalytic properties for its substrate 1,4-BQ when D-galactose was the saturating

359 sugar. Compared to the wild-type enzyme, the turnover numbers for 1,4-BQ with D-

360 galactose as saturated substrate at $30^{\circ} \mathrm{C}$ and at $50^{\circ} \mathrm{C}$ were increased 9-fold and 12 -

361 fold, respectively, for the variant. In combination with a lowered $\mathrm{K}_{\mathrm{M}}$ value for the

362 electron acceptor the resulting catalytic efficiency was 24 times and 15 times higher,

363 respectively, compared to the wild-type enzyme. This property, together with its

364 considerably increased stability, makes this variant particularly promising for 
365 applications in biofuel cells. The bioelectrochemical properties of

366 T169G/E542K/V546C are currently studied in our laboratory.

367

\section{Acknowledgements}

369 Financial support from the Austrian Science Fund (Fonds zur Förderung der 370 wissenschaftlichen Forschung, Translational Project L213-B11) to DH is gratefully 371 acknowledged. CD has been supported by grants from the Swedish Research 372 Council for Environment, Agricultural Sciences and Spatial Planning (Formas), the 373 Swedish Research Council, the CF Lundströms Foundation, and the Carl Tryggers 374 Foundation. We thank the beamline staff scientists at MAX-lab (Lund, Sweden) for 375 support during data collection.

376 The authors have declared no conflict of interest. 
377

378

379

380

381

382

383

384

385

386

387

388

389

390

391

392

393

394 2001, 67, 3636-3644.

395 [7] Haltrich, D., Leitner, C., Neuhauser, W., Nidetzky, B., Kulbe, K. D., Volc, J. A

396 convenient enzymatic procedure for the production of aldose-free D-tagatose. Anal.

397 NY Acad. Sci. 1998, 864, 295-299.

398 [8] Heller, A. Miniature biofuel cells. Phys. Chem. Chem. Phys. 2004, 6, 209-216. 
399 [9] Tamaki, T., Ito, T., Yamaguchi. T. Immobilization of hydroquinone through a 400 spacer to polymer grafted on carbon black for a high-surface-area biofuel cell 401 electrode. J. Phys. Chem. B. 2007, 34, 1012-1039.

402 [10] Tasca, F., Timur, S., Ludwig, R., Haltrich, D., Volc, J., Antiochia, R., Gorton, 403 L. Amperometric biosensors for detection of sugars based on the electrical wiring of 404 different pyranose oxidases and pyranose dehydrogenases with osmium redox 405 polymer on graphite electrodes. Electroanalysis 2007, 19, 294-302.

406 [11] Penning, T. M., Jez, J. M. Enzyme redesign. Chem. Rev. 2001, 101, 3027-3046. 407 [12] Masuda-Nishimura, I., Minamihara, T., Koyama, Y. Improvement in thermal 408 stability and reactivity of pyranose oxidase from Coriolus versicolor by random 409 mutagenesis. Biotechnol. Lett. 1999, 21, 203-207.

410 [13] Salaheddin, C., Spadiut O., Tan, T.-C., Divne, C., Haltrich, D., Peterbauer, C. 411 Probing active-site residues of pyranose 2-oxidase from Trametes multicolor by 412 semi-rational protein design. Biotechnol. J., doi 10.1002/biot.200800265.

413 [14] Spadiut, O., Leitner, C., Tan, T.-C., Ludwig, R., Divne, C., Haltrich, D. 414 Mutations of Thr169 affect substrate specificity of pyranose 2-oxidase from 415 Trametes multicolor. Biocatal. Biotrans. 2008, 26, 120-127.

416 [15] Kujawa, M., Ebner, H., Leitner, C., Hallberg, B., Prongjit, M., Sucharitakul, J., 417 Ludwig, R., Rudsander, U., Peterbauer, C., Chaiyen, P., Haltrich, D., Divne, C. 418 Structural basis for substrate binding and regioselective oxidation of 419 monosaccharides at C3 by pyranose 2-oxidase. J. Biol. Chem. 2006, 46, 3510442035115.

421 [16] Li, S., Wilkinson, M. F. Site-directed mutagenesis: a two-step method using 422 PCR and DpnI. Biotechniques 1997, 4, 588-590. 
423 [17] Bradford, M. M. A rapid and sensitive method for the quantitation of 424 microgram quantities of protein utilizing the principle of protein-dye binding. Anal. 425 Biochem. 1976, 72, 248-254.

426 [18] Laemmli, U. K. Cleavage of structural proteins during the assembly of the head 427 of bacteriophage T4. Nature 1970, 227, 680-685.

428 [19] Splechtna, B., Nguyen, T.-H., Steinböck, M., Kulbe, K. D., Lorenz, W., 429 Haltrich, D. Production of prebiotic galacto-oligosaccharides from lactose using $\beta$ 430 galactosidases from Lactobacillus reuteri. J. Agric. Food Chem. 2006, 54, 49994315006.

432 [20] McPherson, A. Preparation and Analysis of Protein Crystals, John Wiley \& 433 Sons, 1982.

434 [21] Kabsch, W. Automatic processing of rotation diffraction data from crystals of 435 initially unknown symmetry and cell constants. J. Appl. Cryst. 1993, 26, 795-800.

436 [22] Murshudov, G. N., Vagin, A. A., Dodson E. J. Refinement of macromolecular 437 structures by the maximum-likelihood method. Acta Crystallogr. Sect. D 1997, 53, $438 \quad 240-255$.

439 [23] Painter, J., Merritt, E. A. Optimal description of a protein structure in terms of 440 multiple groups undergoing TLS motion. Acta Crystallogr. Sect. D 2006, 62, 439441450.

442 [24] Jones, T. A., Zou, J.-Y., Cowan, S. W., Kjeldgaard, M. Improved methods for 443 building protein models in electron density maps and the location of errors in these 444 models. Acta Crystallogr. Sect. A 1991, 47, 110-119.

445 [25] Emsley, P., Cowtan, K. Coot: model-building tools for molecular graphics. 446 Acta Crystallogr. Sect. D 2004, 60, 2126-2132. 
447 [26] Bastian, S., Rekowski, M. J., Witte, K., Heckmann-Pohl, D. M., Giffhorn, F.

448 Engineering of pyranose 2-oxidase from Peniophora gigantea towards improved

449 thermostability and catalytic efficiency. Appl. Microbiol. Biotechnol. 2005, 67, 654-

450663.

451 [27] Giffhorn, F. Fungal pyranose oxidases: occurrence, properties and biotechnical

452 applications in carbohydrate chemistry. Appl. Microbiol. Biotechnol. 2000, 54, 727453740.

454 [28] DeLano, W. L. The PyMOL Molecular Graphics System, DeLano Scientific, 455 Palo Alto, CA, USA, 2002. http://www.pymol.org.

456 [29] Lovell, S. C., Davis, I. W., Arendall, W. B. 3rd, de Bakker, P. I., Word, J. M.,

457 Prisant, M. G., Richardson, J. S., Richardson, D. C. Structure validation by C- $\alpha$ 458 geometry: $\phi, \psi$, and C- $\beta$ deviation. Proteins $2003,50,437-450$.

459 [30] Rabinovich, M. L., Vasil'chenko, L. G., Karapetyan, K. N., Shumakovich, G.

460 P., Yershevich, O. P., Ludwig, R., Haltrich, D., Hadar, Y., Kozlov, Y. P., 461 Yaropolov, A. I. Application of cellulose-based self-assembled tri-enzyme system in 462 a pseudo-reagent-less biosensor for biogenic catecholamine detection. Biotechnol. J. $4632007,2,546-558$. 
$464 \quad$ Legends to figures

465 Figure 1. SDS-PAGE analysis of purified wild-type P2Ox from Trametes 466 multicolor and the mutational variant T169G/E542K/V546C. Lane 1, molecular 467 mass marker proteins; lane 2, wild-type P2Ox; lane 3, T169G/E542K/V546C after 468 purification by IMAC.

470 Figure 2. Inactivation kinetics of $\mathrm{P} 2 \mathrm{Ox}$ variants from Trametes multicolor at $\mathrm{pH} 6.5$ 471 and various temperatures. A: wtP2Ox and the variant T169G/E542K/V546C at $47260^{\circ} \mathrm{C}$; ; B: •, wild-type P2Ox/variant $\mathrm{T} 169 \mathrm{G} / \mathrm{E} 542 \mathrm{~K} / \mathrm{V} 546 \mathrm{C}$ at $70^{\circ} \mathrm{C}$, the inset 473 shows the inactivation of the triple mutant. Symbols: •, wtP2Ox; $\square$, 474 T169G/E542K/V546C

476 Figure 3. Batch conversion experiments of equimolar mixtures of D-glucose and D477 galactose and oxygen as electron acceptor at both $30^{\circ} \mathrm{C}$ and $50^{\circ} \mathrm{C}$ using wild-type $478 T m \mathrm{P} 2 \mathrm{Ox}$ or the variant T169G/E542K/V546C as biocatalyst.

$479 \mathrm{~A}$, wtP2Ox at $30^{\circ} \mathrm{C} ; \mathrm{B}, \mathrm{T} 169 \mathrm{G} / \mathrm{E} 542 \mathrm{~K} / \mathrm{V} 546 \mathrm{C}$ at $30^{\circ} \mathrm{C} ; \mathrm{C}$, wtP2Ox at $50^{\circ} \mathrm{C} ; \mathrm{D}$, 480 T169G/E542K/V546C at 50 C. Symbols: •, D-glucose; $\boldsymbol{\Delta}$, D-galactose

482 Figure 4. Theoretical models showing the presumed binding of a) $\beta$-D-glucose, and 483 b) $\beta$-D-galactose in the active site of $T$. multicolor P2Ox variant 484 T169G/E542K/V546C based on the crystal structure of P2Ox variant H167A in 485 complex with 2-fluoro-2-deoxy-D-glucose (PDB code 2IGO; [15]). The triple 486 mutant is shown in yellow, and the protein model of 2IGO in light blue (ligand 487 removed). The modeled monosaccharides (glucose and galactose) are shown in light 
488 green. For clarity, protein backbone atoms and water molecules have been omitted.

489 The covalent linkage between the FAD $8 \alpha$ methyl group and His167 $\mathrm{N}^{\varepsilon 2}$ is

490 indicated. The monosaccharides are oriented for oxidation at $\mathrm{C} 2$, and their $\mathrm{C} 4$ atoms

491 are marked by an asterisk (*). Modeling was performed using the program O [24],

492 and the picture was made using MacPyMOL v. 0.98 [28]. 
Table 1. Steady-state kinetic constants of wild-type P2Ox and variant T169G/E542K/V546C with either D-glucose or D-galactose as substrate and $\mathrm{O}_{2}$ (air) as electron acceptor at pH 6.5 and at the temperatures indicated.

\begin{tabular}{|c|c|c|c|c|c|c|}
\hline \multirow[b]{2}{*}{ D-Glucose } & \multicolumn{3}{|c|}{$30^{\circ} \mathrm{C}$} & \multicolumn{3}{|c|}{$50^{\circ} \mathrm{C}$} \\
\hline & $\begin{array}{c}\mathrm{K}_{\mathrm{M}} \\
(\mathrm{mM})\end{array}$ & $\begin{array}{c}k_{\mathrm{cat}} \\
\left(\mathrm{s}^{-1}\right)\end{array}$ & $\begin{array}{c}k_{\text {cat }} / \mathrm{K}_{\mathrm{M}} \\
\left(\mathrm{mM}^{-1} \mathrm{~s}^{-1}\right)\end{array}$ & $\begin{array}{c}\mathrm{K}_{\mathrm{M}} \\
(\mathrm{mM})\end{array}$ & $\begin{array}{l}k_{\text {cat }} \\
\left(\mathrm{s}^{-1}\right)\end{array}$ & $\begin{array}{c}k_{\text {cat }} / \mathrm{K}_{\mathrm{M}} \\
\left(\mathrm{mM}^{-1} \mathrm{~s}^{-1}\right)\end{array}$ \\
\hline wtP2Ox & $0.76 \pm 0.05$ & $34.0 \pm 0.43$ & 44.7 & $1.18 \pm 0.08$ & $58.9 \pm 0.93$ & 50.0 \\
\hline T169G/E542K/V546C & $0.64 \pm 0.10$ & $0.072 \pm 0.003$ & 0.11 & $1.15 \pm 0.12$ & $0.35 \pm 0.008$ & 0.30 \\
\hline \multicolumn{7}{|l|}{ D-Galactose } \\
\hline wtP2Ox & $7.94 \pm 0.39$ & $2.10 \pm 0.03$ & 0.26 & $14.6 \pm 1.57$ & $5.51 \pm 0.16$ & 0.38 \\
\hline T169G/E542K/V546C & $1.66 \pm 0.70$ & $0.27 \pm 0.02$ & 0.16 & $2.76 \pm 0.34$ & $0.74 \pm 0.02$ & 0.27 \\
\hline
\end{tabular}


Table 2. Steady-state kinetic constants of wild-type P2Ox and variant T169G/E542K/V546C for 1,4-benzoquinone as electron acceptor with either D-glucose or D-galactose as saturating substrate. Data were determined at $\mathrm{pH} 6.5$ and at the temperatures indicated.

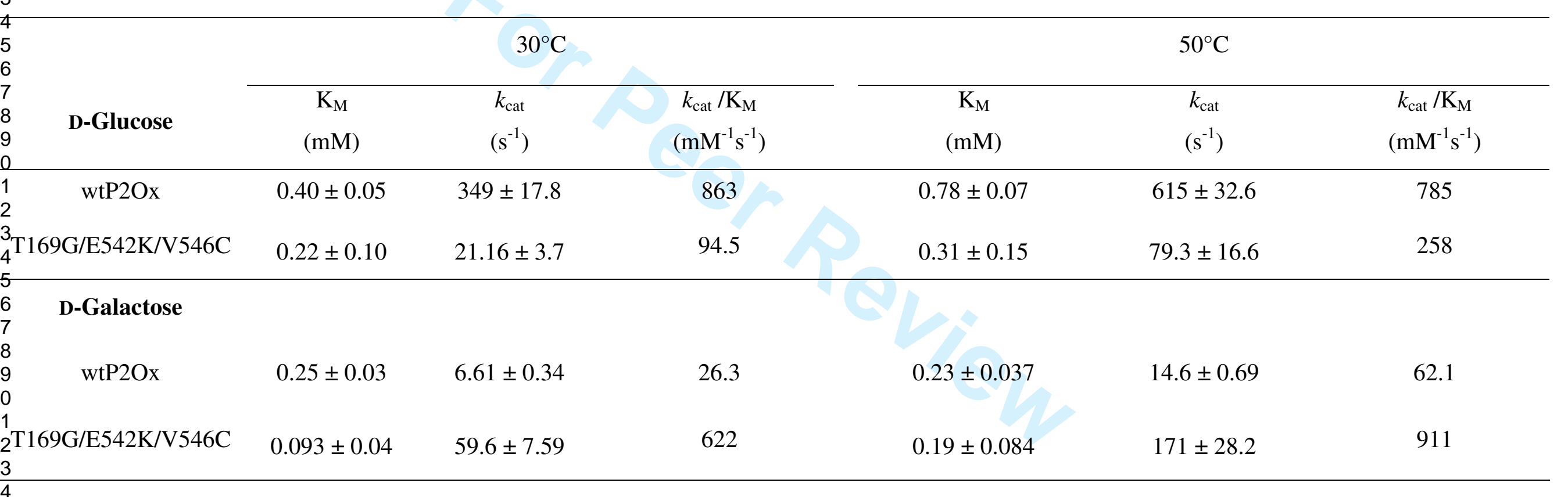


Table 3. Kinetic stability of pyranose oxidase from $T$. multicolor at various temperatures. The inactivation constants $\mathrm{k}_{\mathrm{in}}$ and half-life times of inactivation $\tau_{1 / 2}$ are given for $60^{\circ} \mathrm{C}$ and $70^{\circ} \mathrm{C}$.

\begin{tabular}{ccccc}
\hline Variant & \multicolumn{2}{c}{$60^{\circ} \mathrm{C}$} & \multicolumn{2}{c}{$70^{\circ} \mathrm{C}$} \\
& $k_{\text {in }}\left(\mathrm{min}^{-1}\right)$ & $\tau_{1 / 2}(\min )$ & $k_{\text {in }}\left(\mathrm{min}^{-1}\right)$ & $\tau_{1 / 2}(\min )$ \\
\hline wtP2Ox & $-9.15 \cdot 10^{-2}$ & 7.6 & -5.57 & 0.12 \\
T169G/E542K/V546C & $-1.20 \cdot 10^{-3}$ & 578 & $-1.65 \cdot 10^{-2}$ & 42.0 \\
\hline
\end{tabular}


Table 4. Batch conversion experiments of wild-type pyranose oxidase from $T$. multicolor and the variant T169G/E542K/V546C using equimolar mixtures of D-glucose and Dgalactose at $30^{\circ} \mathrm{C}$ and at $50^{\circ} \mathrm{C}$.

\begin{tabular}{lcccc} 
& batch A & batch B & batch C & batch D \\
\hline Enzyme & wild-type & variant & wild-type & variant \\
Temperature $\left({ }^{\circ} \mathrm{C}\right)$ & $30^{\circ} \mathrm{C}$ & $30^{\circ} \mathrm{C}$ & $50^{\circ} \mathrm{C}$ & $50^{\circ} \mathrm{C}$ \\
Enzyme activity applied $(\mathrm{mU})$ & 1600 & 400 & 2400 & 750 \\
Initial sugar concentration $\left(\mathrm{g} \cdot \mathrm{L}^{-1}\right)$ & 0.8 & 0.3 & 10 & 0.5 \\
Conversion rate D-glc $\left(\mathrm{g} \cdot \mathrm{L}^{-1} \cdot \mathrm{h}^{-1}\right)$ & 2.0 & 0.051 & $8.7 / 2.7^{\mathrm{b}}$ & 0.117 \\
Conversion rate $\mathrm{D}-\mathrm{gal}\left(\mathrm{g} \cdot \mathrm{L}^{-1} \cdot \mathrm{h}^{-1}\right)$ & $0.02^{\mathrm{a}}$ & 0.065 & $0.00^{\mathrm{b}}$ & 0.124 \\
\hline
\end{tabular}

${ }^{\mathrm{a}} \mathrm{D}$-gal was not converted until D-glc was completely oxidized

${ }^{\mathrm{b}}$ during the first 45 min the average conversion rate was high with $8.7 \mathrm{~g} \cdot \mathrm{L}^{-1} \cdot \mathrm{h}^{-1}$, inactivation resulted in a lower average conversion rate of $2.7 \mathrm{~g} \cdot \mathrm{L}^{-1} \cdot \mathrm{h}^{-1}$ over the subsequent 45 min period, wild-type enzyme was completely inactived after 90 minutes 
Table 5. Data collection and refinement statistics

\begin{tabular}{lc}
\hline Data collection $^{1}$ & T169G/E542K/V546C \\
\hline $\begin{array}{l}\text { Cell constants a=b, c }(\AA) ; \beta\left({ }^{\circ}\right) / \text { Space } \\
\text { group }\end{array}$ & $101.58,126.85$ \\
Resolution range, nominal $(\AA)$ & $79.3-1.55(1.60-1.55)$ \\
Unique reflections & $1,581,896(96,227)$ \\
Multiplicity & $16.4(11.3)$ \\
Completeness $(\%)$ & $99.8(97.5)$ \\
$<I / \sigma I>$ & $12.8(2.8)$ \\
$R_{\text {sym }}^{2}(\%)$ & $15.9(88.5)$
\end{tabular}

\section{Refinement}

Resolution range $(\AA)$

$60.0-1.55$

Completeness, all \% (highest bin)

$99.8(98.4)$

$R_{\text {factor }}{ }^{3} /$ work reflns, all

$18.6 / 93,323$

$R_{\text {free }} /$ free reflns, all

$21.9 / 2,899$

Non-hydrogen atoms

5,078

Mean $B\left(\AA^{2}\right)$ protein all/mc/sc

$11.5 / 10.5 / 12.6$

Mean $B\left(\AA^{2}\right)$ solvent /

$\mathrm{N}^{\mathrm{o}}$. molecules

Rmsd bond lengths $(\AA)$, angles $\left(^{\circ}\right) \quad 0.022,1.98$

Ramachandran: favored / allowed $(\%)^{4} \quad 97.7$ / 100

${ }^{1}$ The outer shell statistics of the reflections are given in soft brackets. Shells were selected as defined in XDS [21] by the user.

${ }^{2} R_{s y m}=\left[\Sigma_{h k l} \Sigma_{i}|I-<I>| / \Sigma_{h k l} \Sigma_{i}|I|\right] \times 100 \%$. 
${ }^{3} R_{\text {factor }}=\Sigma_{h k l}|| \mathrm{F}_{\mathrm{o}}|-| \mathrm{F}_{\mathrm{c}}|| / \Sigma_{h k l}\left|\mathrm{~F}_{\mathrm{o}}\right|$

${ }^{4}$ As determined by MolProbity [29] 


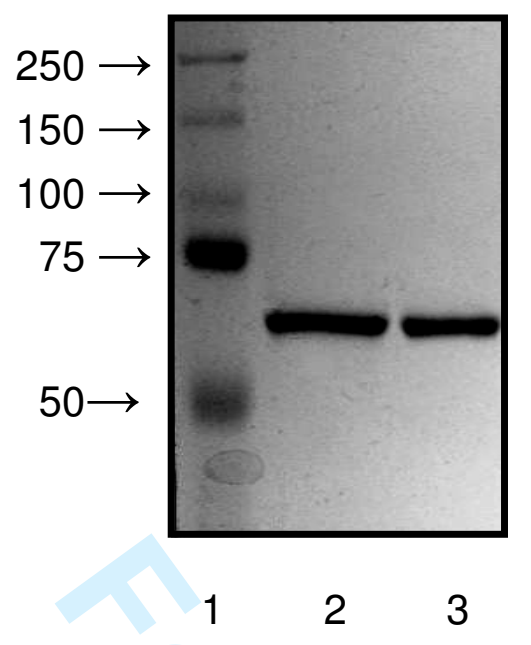



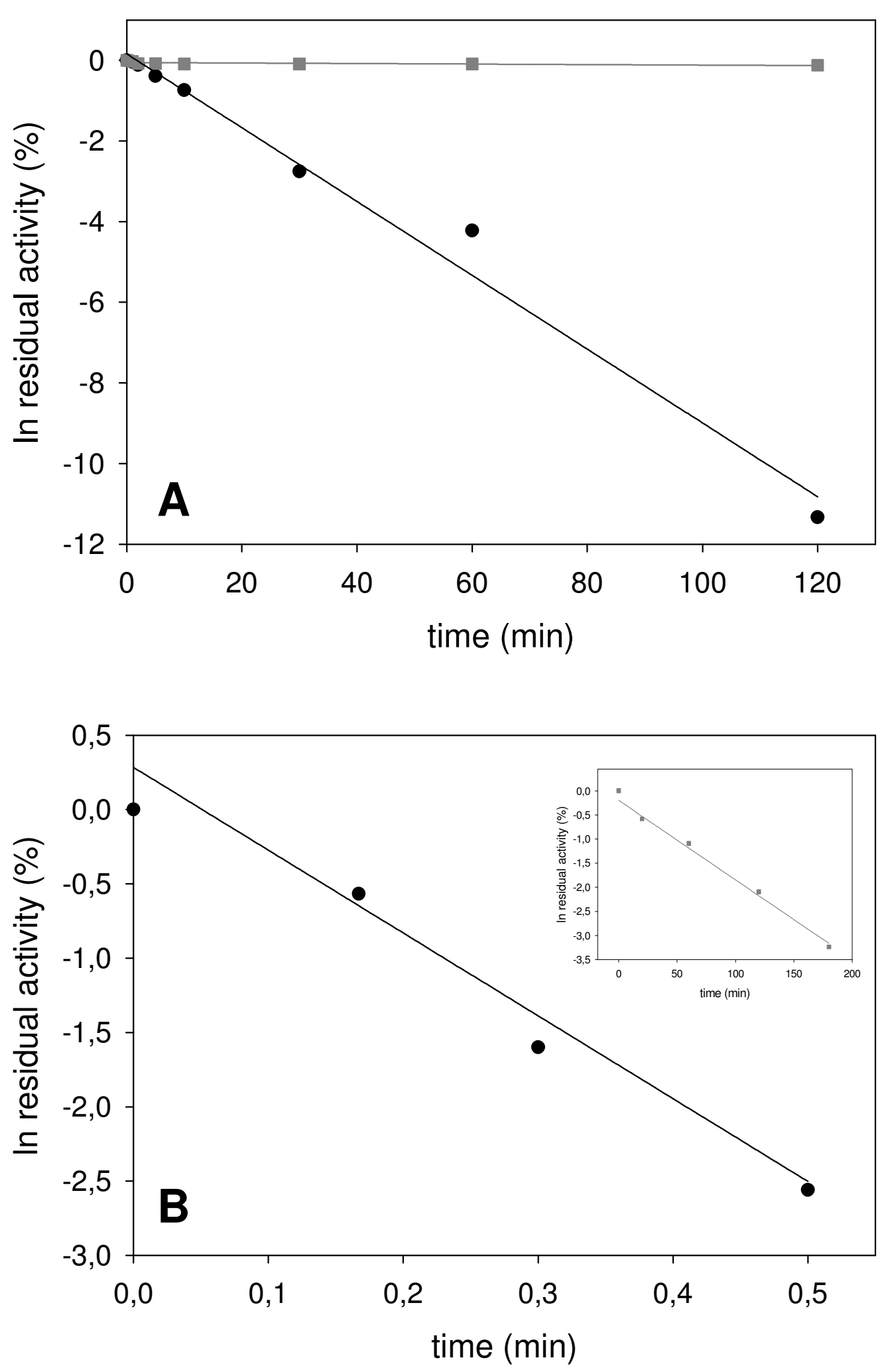

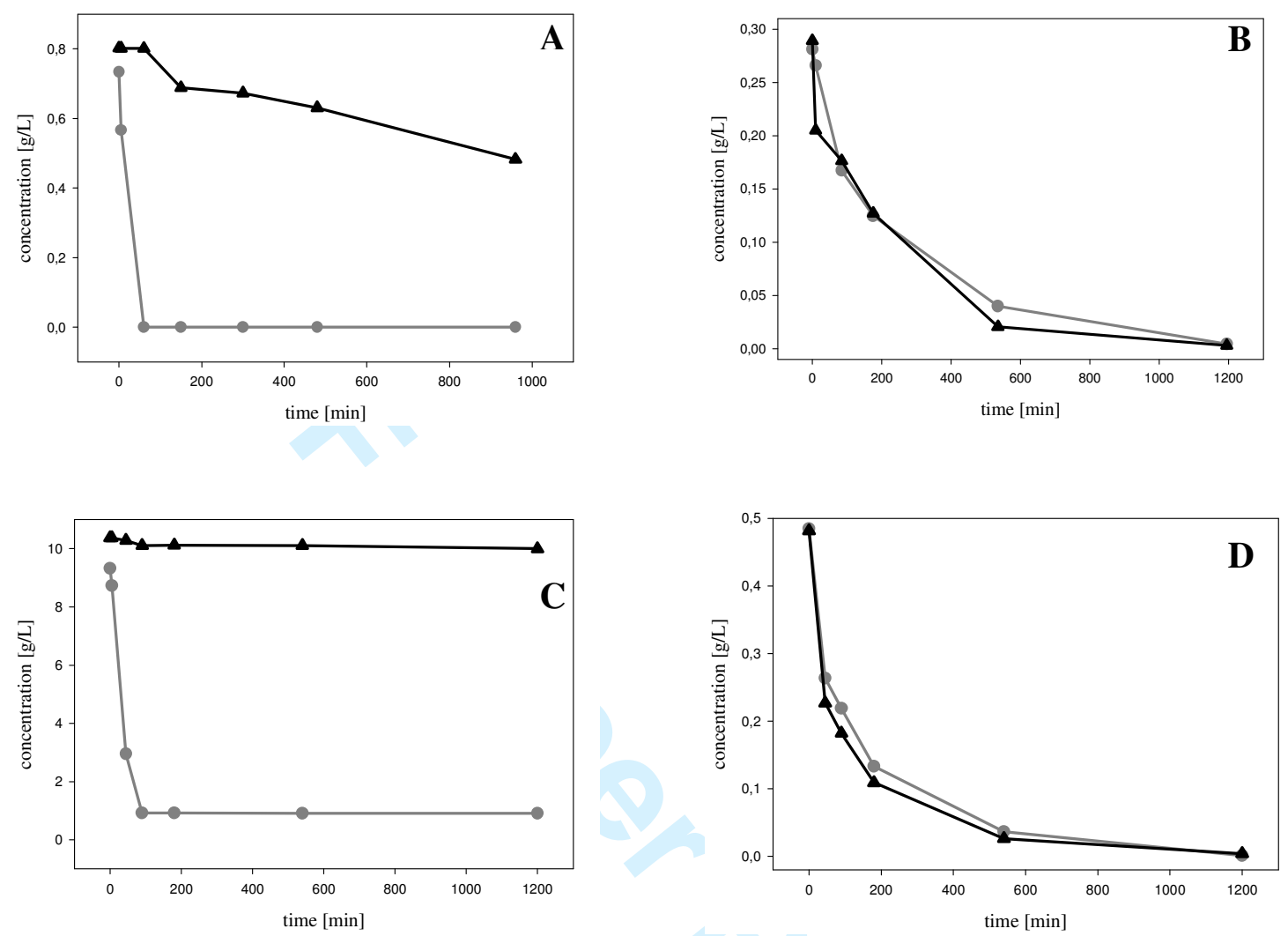

34

35

36

37

38

39

40

41

42

43

44

45

46

47

48

49

50

51

52

53

54

55

56

57

58

59

60 


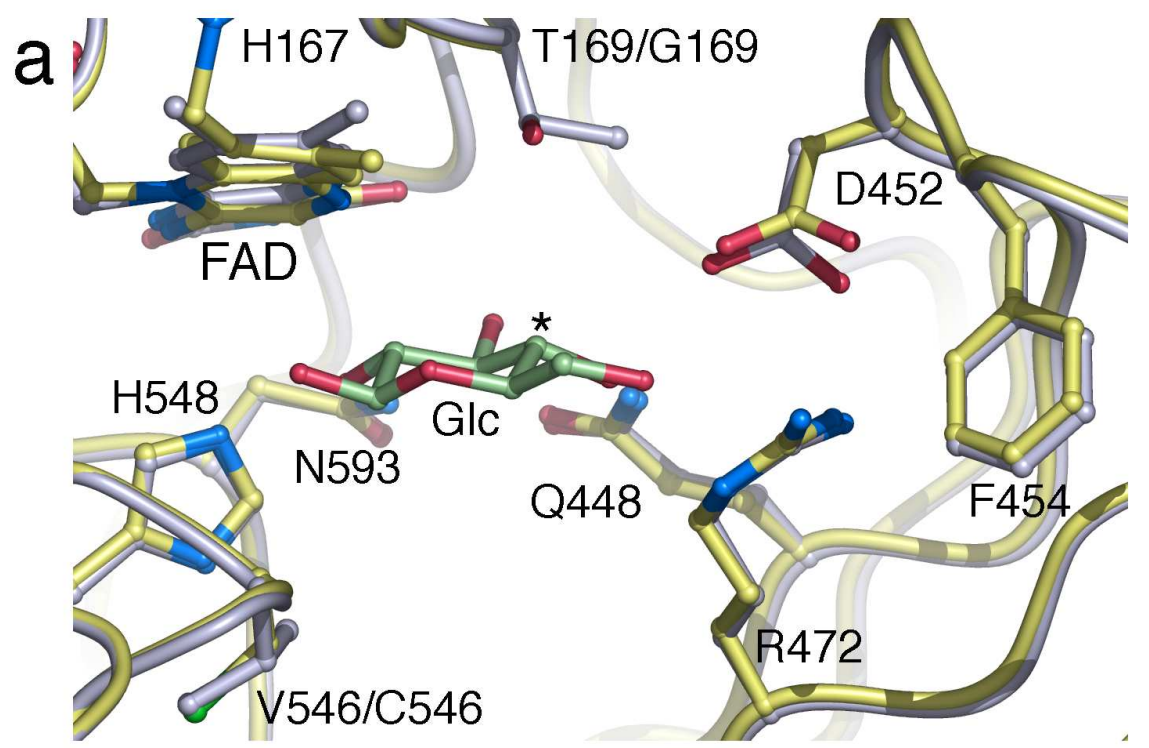

by

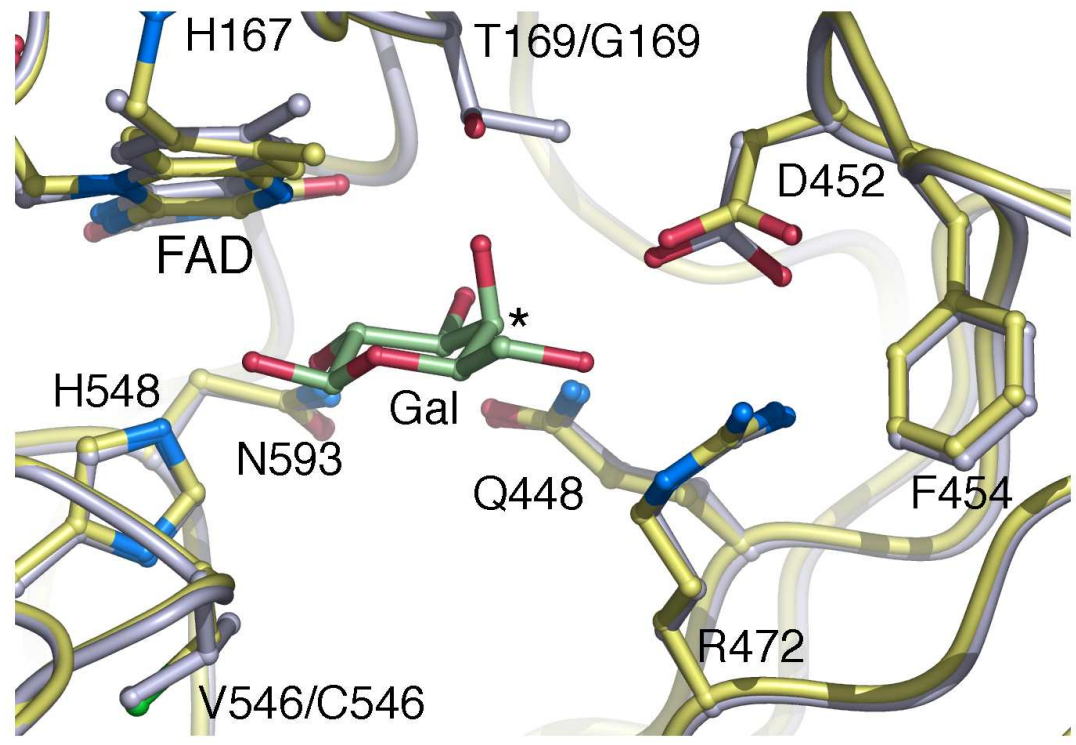

Figure 4

$63 \times 84 \mathrm{~mm}(600 \times 600 \mathrm{DPI})$ 